\title{
Development, characterization and use of microsatellite markers for genetic analysis of Cashew tree (Anacardium occidentale)
}

\author{
Gláucia Buso ${ }^{1 *}$, Natalia Lamas', José Jaime Cavalcanti², Marco Antonio Ferreira ${ }^{1}$ \\ From IUFRO Tree Biotechnology Conference 2011: From Genomes to Integration and Delivery \\ Arraial d'Ajuda, Bahia, Brazil. 26 June - 2 July 2011
}

\section{Background}

The cashew tree (Anacardium occidentale) is found throughout the Brazilian territory, although it is better adapted to the northeastern coast climate. This fruit crop is essential to the agroindustry of the States of Ceará, Piauí and Rio Grande do Norte, where around 95\% of the production is harvested and where the whole processing of the chestnut is done. It currently represents 157 million dollars in exports of nuts. Despite its socio-economic importance it still lags behind in the adoption of breeding technologies. There is very little information about the genetics of this species and no molecular tools yet developed. In this work we developed and characterized a set of microsatellite markers for Anacardium occidentale from the construction of genomic libraries enriched for repetitive sequences.

\section{Material and methods}

The markers developed were used in studies of genetic relationships among samples of the germplasm bank, and saturation of existing genetic maps of the species. Genomic libraries enriched for microsatellites were constructed and out of the 5,472 selected clones, 540 were sequenced and analyzed for the presence of microsatellites. A total of 117 sequences containing microsatellites were selected to design PCR primers and screen the resulting markers. One hundred pairs of primers were synthesized and initially tested for amplification in agarose gel. Fourteen markers were selected and characterized by fluorescent detection in an ABI 377 sequencer based on genotyping a representative set of 35 samples derived from the germplasm collection. Genetic

* Correspondence: buso@cenargen.embrapa.br

${ }^{1}$ Embrapa Cenargen, Brazilia, DF, Brazil

Full list of author information is available at the end of the article parameters such as observed heterozygosity (Ho), expected heterozygosity (He), polymorphic information content (PIC) and power of exclusion (PE) for paretage testing were estimated.

\section{Results}

Great variability in analytical performance was seen among the tested microsatellite markers.Marker AOBR48, for example, proved to be the marker with the highest polymorphic information content. Analysis of accessions from the germplasm collection using microsatellite markers indicated that cashew and a commonly used dwarf clone likely have distinct origins, since they were separated into different groups based on similarity coefficients. Additionally, A. microcarpum, used as an outgroup control, clustered with accessions of the giant type. An F1 population derived from a cross between the dwarf cashew variety (CCP1001) and the giant type (CP 96) was used to map these microsatellites. Among the hundred new markers developed in this study, 11 showed segregation of alleles from the female parent (CCP 1001) in the F1 population, while 21 showed segregation of alleles from the male parent (CP 96). Only three of the 100 tested markers were fully informative showing segregation of alleles from both parents in the F1 population. In total 29 markers could be mapped in this population and 11 markers were positioned in both, the male and female maps.

\section{Conclusions}

An initial set of microsatellites was developed for the Cashew tree. These new markers can be useful for a number of applications in germplasm analysis and breeding. The identification of duplicate accessions in the current germplasm collection, the study of genetic 
diversity in natural populations, represent immediate potential applications to better understand the existing diversity available to breed better clones. Genetic mapping of QTLs for some economically important traits such as increased yield and quality of fruits and cashew, and resistance to diseases could be future targets provided a higher marker density is achieved.

Author details

'Embrapa Cenargen, Brazilia, DF, Brazil. 'Embrapa Agroindustria Tropical, Fortaleza, CE, Brazil.

Published: 13 September 2011

doi:10.1186/1753-6561-5-S7-P157

Cite this article as: Buso et al:: Development, characterization and use

of microsatellite markers for genetic analysis of Cashew tree

(Anacardium occidentale). BMC Proceedings 2011 5(Suppl 7):P157.

Submit your next manuscript to BioMed Central and take full advantage of:

- Convenient online submission

- Thorough peer review

- No space constraints or color figure charges

- Immediate publication on acceptance

- Inclusion in PubMed, CAS, Scopus and Google Scholar

- Research which is freely available for redistribution

Submit your manuscript at www.biomedcentral.com/submit
C Biomed Central 